\title{
Shakespeare in Gujarati: A Translation History
}

SUNIL SAGAR

\begin{abstract}
Translation history has emerged as one of the most significant enterprises within Translation Studies. Translation history in Gujarati per se is more or less an uncharted terrain. Exploring translation history pertaining to landmark authors such as Shakespeare and translation of his works into Gujarati could open up new vistas of research. It could also throw new light on the cultural and historical context and provide new insights. The paper proposes to investigate different aspects of translation history pertaining to Shakespeare's plays into Gujarati spanning nearly 150 years.
\end{abstract}

Keywords: Translation History, Methodology, Patronage, Poetics.

\section{Introduction}

As Anthony Pym rightly (1998: 01) said that the history of translation is "an important intercultural activity about which there is still much to learn". This is why history of translation has emerged as one of the key areas of research all over the world. India has also taken cognizance of this and initiated efforts in this direction. Reputed organizations such as Indian Institute of Advanced Study (IIAS) and Central Institute of Indian Languages (CIIL) have initiated discussion and discourse on this area with their various initiatives.

Translation history has been explored for some time now and it's not a new area per se. However, there has been a paradigm shift in the way translation history is approached in the recent times. As Georges L. Bastin and Paul F. Bandia (2006: 11) argue in Charting the Future of Translation History: 
While much of the earlier work was descriptive, recounting events and historical facts, there has been a shift in recent years to research based on the interpretation of these events and facts, with the development of a methodology grounded in historiography. Translation in history is now being linked to themes such as otherness, ideology, manipulation, and power. Clearly, progress has been made, and the history of translation has become a viable independent research area within translation studies.

In spite of the potential that history of translation has to offer, it has not been explored as much as it should be. As Lieven D'hulst (2017: 21) said "the history of translation has not received the attention it merits in terms of research and cannot be compared to any other type of research in translation studies." We have yet to dwell upon the way culturally central texts were translated and the history around it. We have yet to explore how knowledge texts were rendered and how translators went about their work in this regard. We have yet to decode the translation history of the colonial encounter. The reason why it is vital to explore the translation history is because it will facilitate a better and clearer understanding of the selection of texts, the reception and transfer of texts, translator inclinations and biases, translation scholars and fellow writers and the role they played, patrons and their politics and the over-all historical context in which all this transpired.

As D'hulst (2010: 397) said, "research in translation history cannot be compared to any other type of research". How Shakespeare's works were received and translated is a fascinating site of investigation. It has the potential of offer new insights into the way Gujarati translators behaved in their 
dealings with Shakespeare. The way they made their choices in terms of what is fit for translation and what is not forms an integral part of exploration in terms of translation history. How each translator approached the process of translation with respect to Shakespeare's works can help us understand how translation and translator evolved over a period of more than 150 years of engagement with Shakespeare. It began with adaptations but the thrust is upon translations and the history that surrounds the translations proper.

Since translation history is an emerging area and India has yet to it bit to evolve its methodology for pursuing translation history, it is necessary to dwell upon the issues regarding how translation history can be explored.

\section{Translation History: Possible Methodologies}

Since translation is a complex process in its own right, its history is bound to pose a few challenges for the translation historian. It is possible to approach translation history in various ways. At present, the model of translation history that exists entails listing major translations and if possible, mentioning the names of the translators and the year of publication etc. in a way that creates a sort of chronological account of translations.

There are two primary ways to evolve a methodology that suits our respective translation history endeavours:

\section{Devising a Methodology based on Translation Theory and Discourse}

The West has invested heavily in translation history in the last 30 years of so. It has led to a number of publications on the subject and discourse on translation history has only grown with each publication and argument. 
Insights related to translation history are scattered all over the arguments put forward by different translation scholars. It is necessary to glean the insights and customize them for the Indian context. Accordingly, it would be possible to arrive at a methodology for translation history and carry out the concrete work in terms of translation history.

It's interesting to note what the different translation scholars have to say regarding translation history in the West.

Susan Bassnett and Harish Trivedi (1999) have frequently argued that translation needs to be contextualized and should be studied in the light of a number of factors that affect it. Unless we study how a translation occurred and how it was affected by different factors, it is not possible to arrive at any reliable understanding of a translation:

In a similar vein, in General Editors' Preface to Translation/History/Culture, Bassnett and Lefevere (1999) argue how translation occurs and the way it is shaped by different forces. In their view, translation is a rewriting and all rewritings have their ideology and poetics that needs to be investigated into.

As Gentzler and Tymoczko (2002: xxi) assert that translation is, in fact, "a deliberate and conscious act of selection, assemblage, structuration, and fabrication- and even, in some cases, of falsification, refusal of information, counterfeiting, and the creation of secret codes." Gentzler and Tymoczko also believe that translators are not mere translators but they, "as much as creative writers and politicians, participate in the powerful acts that create knowledge and shape culture".

Thus, translation and power are not two separate subjects; power is, in fact, 'inherent in the translation process itself'. The translation theorists have argued for a long time that that "[t]he key topic that has provided the impetus for the new 
directions that translation studies have taken since the cultural turn is power" (Gentzler/Tymoczko xvi).

One can go on quoting from these eminent translation scholars but it is evident that each translation scholar had something pertinent to say about translation history which can be made use of while charting the course of translation history. Whether it's patronage, translator's choices or the influence of translation scholars on what and how any text gets translated, there are ideas scattered all over the volumes pertaining to Translation Studies. It will require an effort but it's possible to identify the key ideas and construct a methodology that can be useful and effective in unravelling translation history more precisely and more comprehensively.

\section{Deriving a Methodology based on Case Studies}

In case, theory is not enough as to how translation history should be approached, there are quite a few practical examples of work done by some translation historians from which we can derive insights and evolve a methodology for translation history. Although there are several such examples, one practical example from which one could evolve a model of methodology is shared here to put it into perspective.

Here's an excerpt from the tribute to the late Daniel Simeoni who is credited with commendable work with respect to translation history. The excerpt illustrates how he pursued translation history in his unique way. It is markedly different from the way India practices translation history today. It is unique because of the sheer multitude of strategies that Simeoni employs and sources that he explores compared to our practice of only reading major books related to a subject. The way he explored translation history could be adapted and adopted as a methodology of pursuing translation history. Hélène Buzelinet Deborah Folaron (1990) writes in "To the memory of Daniel Simeoni": 
Since 2002, Daniel Simeoni carried out a historiographical project on Domenico Valentini, author of the first complete translation of Shakespeare's Julius Caesar in Italy (1756). He had followed the trail of his author to Sienna, and for a year combed libraries, scrutinized boxes of archival materials, and consulted with experts. In searching for clues, he had finally discovered unexpected links between the fate of his writer and the political plots in Italy at the time (3).

This comes close to the work that one needs to undertake with respect to translation history related to Shakespeare's plays rendered into Gujarati.

In summation, one can say that there's no one rigid methodology that one can impose on all translation history projects. In the context of a particular project, we need to evolve a methodology that suits our purposes related to translation history. In sync with this insight, a methodology to document the nuances of the historical context in which these translations of Shakespeare's works occurred was evolved based on a combination of these insights from the theory and practical examples of practices of translation historians.

\section{Gujarat's Tryst with Shakespeare}

Gujarat shares a unique relationship with Shakespeare starting as early as 1852 . When the engagement with Shakespeare in India began in the form of adaptations, an adaptation of Shakespeare's Taming of the Shrew titled as Nathari Firangiz Thekane Aavi in Gujarati was performed by a Parsi theatre group at Andrews Library in Surat in 1852. This was the first ever adaptation of a Shakespearean play in any modern Indian language. 
Since then, this engagement only grew stronger with further adaptations for nearly half a century. Translations proper began to appear only from 1898 , the end of the $19^{\text {th }}$ century and the beginning of the $20^{\text {th }}$ century. While translations went on in the first half of the $20^{\text {th }}$ century, the full flowering of translation endeavours occurred only in the $2^{\text {nd }}$ half of the $20^{\text {th }}$ century with a number of translations taking place after 1960 .

Those who translated a full text of Shakespeare's play definitely form a part of translation history but it should also be kept in mind that there were those who celebrated Shakespeare without translating his plays. There were also those who carried out scholarly writing about his plays in Gujarati. A set of Gujarati scholars who did not translate Shakespeare's plays played a vital role in shaping the translation history because they provided the methodology for translations and also lent the necessary guidance and support.

To exemplify the categories of scholars and writers associated with translation history of Shakespeare's plays, it would be necessary to dwell upon a few aspects other than the translations of his plays. To start with, every major scholar, writer, poet and critic in Gujarati read and commented upon Shakespeare's works somewhere or the other. Keshav Harshad Dhruv, the Sanskrit scholar and translator, went to the extent of conceptualizing a metre called "Vanveli" that could lend itself to the translation of Shakespeare's plays. As the $2^{\text {nd }}$ President of Gujarati Sahitya Parishad, Dhruv (1939) delivered a discourse wherein he says:

In English schools and other schools, we come to experience new phenomenon. When we see Shakespeare's plays being performed on the stage, we get the true realization of how verse can be recited. Based on the new experience, a question arises that why Gujarati dramas cannot have the same 
phenomenon of verse being sung....To see whether the necessary verse elements can be ushered in our verse composition and how it can be done, I have conceptualized "Vanveli" (118) (Translation mine).

This discourse became a part of Dhruv's Sahiyta ane Vivechan (Literature and Criticism). He then goes on to provide a rendering of Act III, Scene II of Julius Caesar using Vanveli in place of Blank Verse. This is significant because it was deemed difficult to translate Shakespeare in Gujarati partly because it necessitated the use of a metre in verse form. Dhruv's "Vanveli" was believed to be freer in the way it would be suitable for translation of Shakespeare's plays.

B. K. Thakore (1869-1952) and R. V. Pathak (1887-1955) wanted to see Shakespeare rendered in Gujarati and lamented about how major Gujarati poets have failed to usher in Shakespeare in Gujarati. Hansa Mehta (1897-1995) who translated two of Shakespeare's plays into Gujarati refers to how the above-mentioned scholars inspired her translation work. Vishuprasad Trivedi (1899-1991), a veteran scholar whom Umashankar Joshi (1911-1988) refers to as one of the few teachers who could teach English and Gujarati literature equally well also took in interest in Shakespeare studies and translation. He went through the translations of Mohamed Rupani (1912-2016) and shared his valuable feedback and inputs for improvement of the same. Regardless of everything else, he should also be remembered as the teacher of another great Shakespearean scholar namely, Santprasad Bhatt (19161984), popularly known as S. R. Bhatt. Santprasad Bhatt devoted himself to the study of Shakespeare's works and motivated several others to explore Shakespeare in this way. Bhatt also went through Rupani's Gujarati translation of As You Like It and Sonnets and provided his feedback. In his preface to Bhatt's book titled Shakespeare, Umashankar Joshi, 
who was the editor of Sanskriti, a Gujarati literary magazine published on a monthly basis, recalls his conversation with Bhatt (1970):

The year of Shakespeare's 400th birth anniversary was inching closer. In 1961, I had tried to include articles related to Tagore on his $100^{\text {th }}$ birth anniversary throughout the year in Sanskriti. What would I do regarding Shakespeare? It was a surprise to see and hear what I did; Santprasad Bhatt had come to my place on his own and said, "We must do something next year for Shakespeare. I will contribute something every month." I said, "There should be no lapse in any month" And he said, "Alright" (8).

These articles were later compiled and published as a book titled Shakespeare published by Gujarat University in 1970. In the preface, Umashankar Joshi also cites examples of how Bhatt provides delightful translation of some of the lines and titles of Shakespeare's plays and sonnets in this book. The articles are testimony of Bhatt's scholarship and his life-long fascination for Shakespeare.

Umashankar Joshi was probably the most influential scholar in terms of translation history related to Shakespeare. His fascination for Shakespeare endured a lifetime and he generously contributed in terms of facilitating the translation of Shakespeare's works into Gujarati. His initiation into Shakespeare happened quite early in life. The article titled "Shakespeare nu Collar" (Shakespeare's Collar) adequately documents Umashankar Joshi's fondness for Shakespeare even as a school-going boy. As he says :

"I was studying the fifth grade English medium in a school in Idar. At that time, a theatre company called 'Shakespeare Natakmandali' had come. The board that carried the name of the company had a picture of 
Shakespeare with his famous collars not properly done. It is still fresh in mind as a memory as to how I, along with some friends, keeping Empire History by my side, went there to alter the collars and set it right" (55).

As a young student, he developed such keen interest in Shakespeare's works that went on the shape a part of translation history of Shakespeare in Gujarati.

He initiated a project involving translation of 15 texts and included Shakespeare's Othello as one of the texts. He asked Mansukhlal Jhaveri to translate the same into Gujarati. He also reached out to Nalin Rawal to translate Shakespeare's The Tempest. At the time of $400^{\text {th }}$ anniversary of Shakespeare's birth, Joshi decided to dedicate the publications of all issues of Sanskriti of an entire year to Shakespeare. The cover page of the magazine carried Shakespeare's photograph and it also carried the line under the photograph indicating the $400^{\text {th }}$ birth anniversary. Since Shakespeare was born in the month of April, Umashankar Joshi decided to prepare a special issue on Shakespeare in April issue of Sanskriti in 1964. The index of the issue carried a poem written by Umashankar Joshi followed by excerpts of translations by the well-known scholars such as Karsandas Manek, Mansukhlal Jhaveri, Hansa Mehta, Ushanas etc. It also carried scholarly articles by Santprasad Bhatt, C. C. Mehta, Jayant Pathak and Niranjan Bhagat etc. It carried a special translation of Hamlet's famous soliloquy "To be or not to be, that is the question" by Umashankar Joshi himself. As a translation, it ranks with the best of translations of Shakespeare's works.

Each issue starting from January carried the photograph of Shakespeare with a line indicating $400^{\text {th }}$ anniversary of Shakespeare's birth. Here's the cover page of January and the index of a special April issue of Shakespeare: 
Shakespeare in Gujarati:...

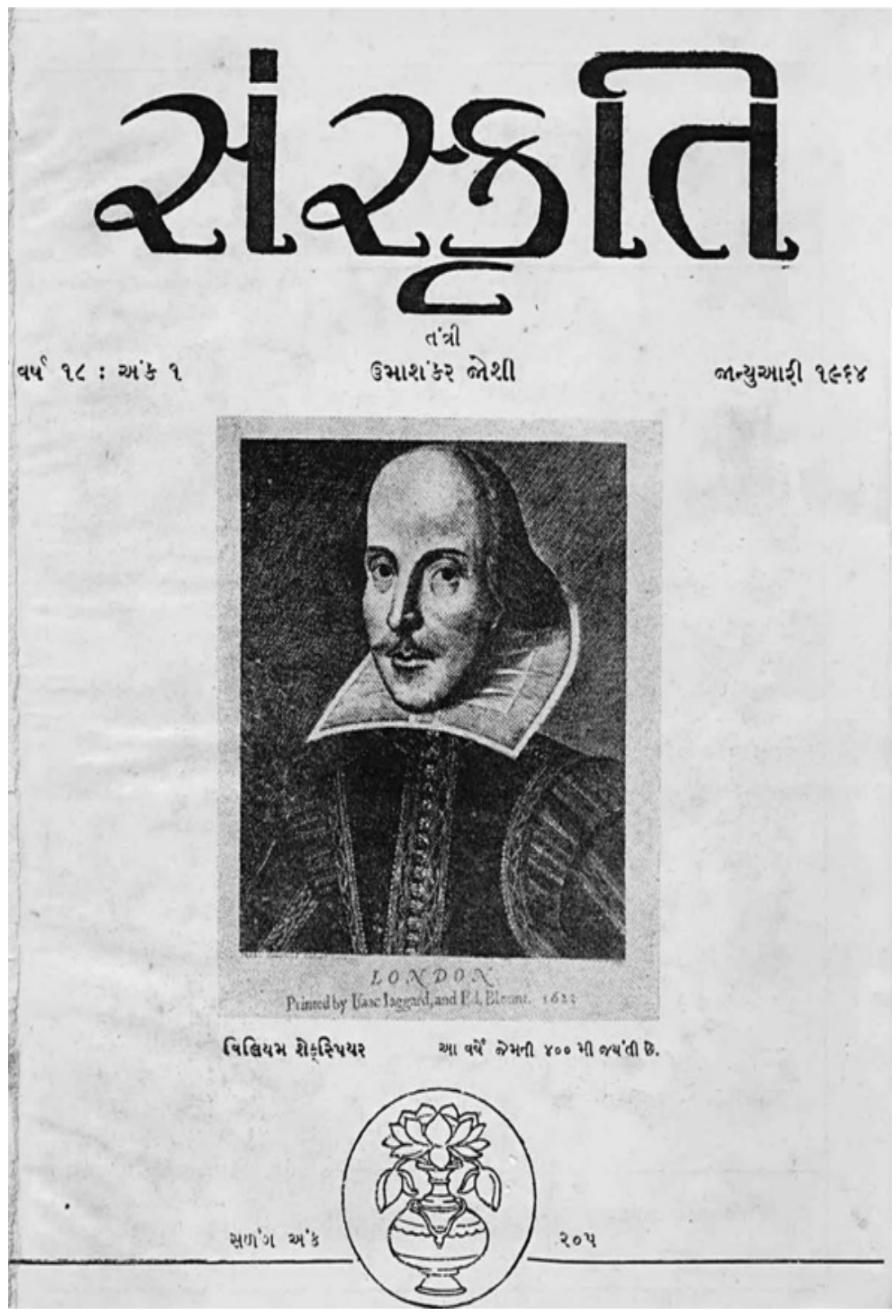




\section{સંસ્કૃતિ}

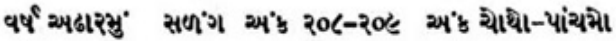

\begin{tabular}{|c|c|c|}
\hline \multicolumn{3}{|c|}{ અનુક્રમણિક : એપ્રિલ-મે ૧૯૬૬ } \\
\hline 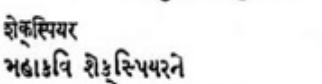 & $\begin{array}{l}\text { ઉभાશં tર નેરી } \\
\text { મૂસિકાર }\end{array}$ & \\
\hline 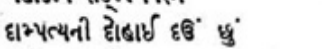 & અનુ. કરસનદાસ માણેેક & \\
\hline 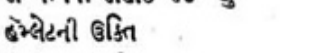 & અનુ. મનસુખલાલ ઝવરે & \\
\hline भોકબેयनी ઉક્તિ & અनु. बંसा भछेता & \\
\hline : યાર શૈના & રધુવીર યौધરી & \\
\hline ओ स्व & અનુ. ઉમાશં કર ભેરil & \\
\hline શેકુસ્સિપ્પ & $\begin{array}{l}\text { મેં્યુ આન્લs } \\
\text { અનુ. ઉશનસ્ }\end{array}$ & \\
\hline શોક્સ્પિપ4રની વાત & 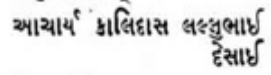 & \\
\hline 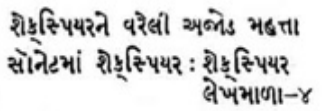 & $\begin{array}{l}\text { خ્રે. ફીરાઝ કા. દાવર } \\
\text { સન્તત્રસાદ ભદ }\end{array}$ & \\
\hline 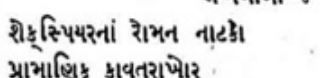 & $\begin{array}{l}\text { પ્રે. શી|રીન भુક્ચેડકર } \\
\text { જ્યન્ત દ્લાલ }\end{array}$ & \\
\hline 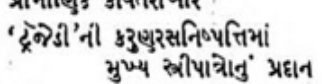 & 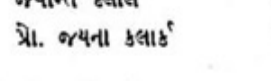 & \\
\hline ब्सेट & ઉમેદબાઈ મણિયાર & \\
\hline 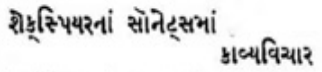 & $0 x^{4}+c$ & \\
\hline $\begin{array}{l}\text { શેક્સિપ્રિની ગુજ્રાતી રંગભૂમિ } \\
\text { ઉ૫ર અસર }\end{array}$ & યન્ફવદન મઠેતા & \\
\hline સ્વખ્ન અને પડળાયા & દિગીશ મહેતા & \\
\hline 'ધ ફીનિકસ ચ' & निरंજન & \\
\hline & शil & \\
\hline
\end{tabular}

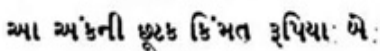

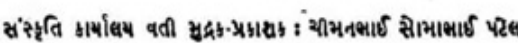

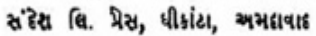

\section{सूયનાઓ :}

दर भાસની દसभી તારીખ ચાं प्रस्विध् थाय

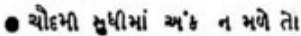

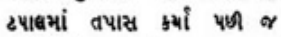

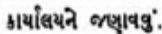

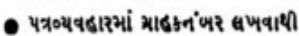
સગવડ થરો.

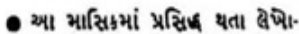
માંના અભિપ્રાય માટેની જ્વાણદરી ते त बढพเनी 0.

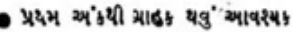

จ.

শાષ્। નાંધવાનાં स्थणे :

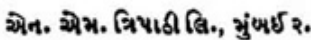

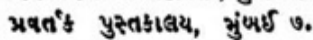

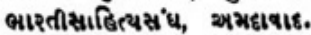

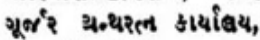
ॠમธાષાร.

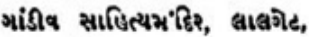
સુરस.

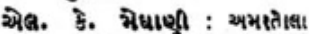
स्द्रीट, કबक्ता १.

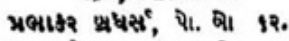

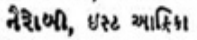
बखा०น :

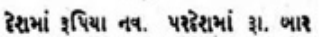

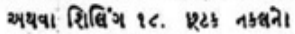
अतिये ओष.

लाइशખभરना ह२

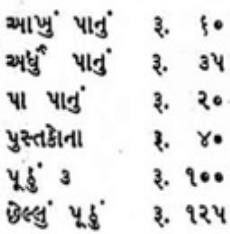
તંગ્રી અને વ્યવસ્થા અ'ગેના સધળા પત્રવ્યવહારું સરનામું :

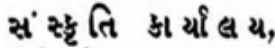
એલિસ-થ્રિજ, અમદાવાદ-ई 
On the occasion of $400^{\text {th }}$ anniversary of Shakespeare's birth, C. C. Mehta conceptualized Drashyavali, a compendium of scenes translated from Shakespeare's plays to be performed in schools. It carried interesting translations and transcreations by Keshav Harshad Dhruv, R. V. Pathak, C. C. Mehta, Dhansukhlal Mehta, Hansa Mehta, Pragji Dosa, Jashwant Thakar, Gulabdas Broker etc. It was an effort to pay tribute to Shakespeare through performance. C. C. Mehta himself contributed a translation of a scene of Shakespeare's $A$ Midsummer Night's Dream for the volume. Mehta had also written an article titled, "Shakespeare and Gujarati Stage" in Indian Literature Vol. 7, Issue I in 1964 documenting Shakespeare's plays were adapted and appropriated on Gujarati stage.

Generation by generation, scholars, critics, writers, poets and translators engaged with Shakespeare over a period of nearly 170 years in myriad different ways by critiquing, revisiting, translating and discoursing over Shakespeare's many timeless works. Translation history would be incomplete without taking into account the historical context of the cultural and intellectual discourses of the $19^{\text {th }}$ and $20^{\text {th }}$ century Gujarat and its literature. Such a rich cultural and literary ambiance would naturally lead to many endeavours in the direction of translation of Shakespeare's plays. These translations coupled with the historical context as rich as described above make a great site for the exploration into translation history.

\section{Shakespeare in Gujarati: A New Model of Translation History}

Based on the insights cited above, a new methodology for the study of translation history related to Shakespeare's works translated into Gujarati has been worked out. It is as follows:

1. Study the Translator First, then the Translation

2. Selection of the Text for Translation 
Sunil Sagar

3. Poetics

4. Support Mechanisms and Interventions

5. Patronage and Censorship

6. When did the translation occur?

7. Where did the translation occur?

8. Blank Spaces, Mistakes and Forgotten Translations

Before delving into the detailed translation history, it may be apt to consider the translator-wise chronology of Gujarati translations of Shakespeare's plays:

\begin{tabular}{|c|c|c|c|}
\hline $\begin{array}{l}\text { Sr. } \\
\text { No. }\end{array}$ & Translator & Text & Year \\
\hline 1 & Bhanji Gokul Parekh & Julius Caesar & 1874 \\
\hline \multirow[t]{5}{*}{2} & \multirow{5}{*}{$\begin{array}{l}\text { Narbeshankar } \\
\text { Pranjivan Dave }\end{array}$} & Othello & 1898 \\
\hline & & Julius Caesar & 1898 \\
\hline & & $\begin{array}{ll}\text { Measure } & \text { for } \\
\text { Measure } & \end{array}$ & 1905 \\
\hline & & $\begin{array}{l}\text { The Merchant of } \\
\text { Venice }\end{array}$ & 1911 \\
\hline & & Hamlet & 1917 \\
\hline \multirow[t]{2}{*}{3} & \multirow[t]{2}{*}{ Hansa Mehta } & Hamlet & 1942 \\
\hline & & $\begin{array}{l}\text { The Merchant of } \\
\text { Venice }\end{array}$ & 1944 \\
\hline \multirow[t]{4}{*}{4} & \multirow[t]{4}{*}{ Jayant Patel } & Othello & 1963 \\
\hline & & Macbeth & 1963 \\
\hline & & $\begin{array}{l}\text { The Merchant of } \\
\text { Venice }\end{array}$ & 1964 \\
\hline & & As You Like It & 1964 \\
\hline \multirow[t]{2}{*}{5} & \multirow[t]{2}{*}{ Jashwant Thakar } & Macbeth & 1964 \\
\hline & & Richard III & 1969 \\
\hline
\end{tabular}


Shakespeare in Gujarati:...

\begin{tabular}{|l|l|l|l|}
\hline 6 & \multirow{2}{*}{ Mansukhlal Jhaveri } & Hamlet & 1967 \\
\cline { 3 - 4 } & & Othello & 1978 \\
\cline { 2 - 4 } & & King Lear & 1983 \\
\hline 7 & $\begin{array}{l}\text { Krushnashankar } \\
\text { Ambashankar Vyas }\end{array}$ & $\begin{array}{l}\text { The Merchant of } \\
\text { Venice }\end{array}$ & 1975 \\
\hline 8 & Mohamed Rupani & $\begin{array}{l}\text { Shakespeare's 159 } \\
\text { sonnets }\end{array}$ & 1977 \\
\cline { 3 - 4 } & & As You Like It & 1979 \\
\hline 9 & Nalin Rawal & The Tempest & 1992 \\
\hline
\end{tabular}

A detailed exposition of each of the above-mentioned criteria with respect to Shakespeare's works in Gujarati is as follows:

\section{First Principle: 'Study the Translator First, then the Translation'}

In recent times, there's a growing emphasis on putting spotlight on the translator. In many ways, it's pertinent as well. It's not for the purpose of merely focusing on the human side of it but also for the purpose of throwing more light on translation process, the historical context and much more. As a human being, the translator may be influenced by a number of factors which may, in turn, affect the translation. There are several instances of this that can be found in translation history if we look closely. Hence, in approaching translation history pertaining to Shakespeare's plays in Gujarati, it would be apt to focus on the translator first and then study the translations.

Mumbai Samachar, a leading Gujarati daily, once upon a time, carried an article titled "A Forgotten Translator"; the date and columnist's names are not available at the moment. It was an article on Narbheshankar Pranjivan Dave (1870-1952), the one of the first few translators who translated Shakespeare's plays into Gujarati. These are not adaptations but proper translations. He carried the pen name 'Kathiawadi'. 
This is not merely the story of a single translator; this is largely the narrative of each Shakespearean translator in Gujarati. We know little about them in any sense of the word.

It is still a mystery as to where they came from, where they worked, how they dealt with the challenges of rendering Shakespeare in Gujarati.

If the purpose is to 'humanize' translation, one must start with translators!

Here're a few case studies of how translator's life and work are, at times, crucial for translation history:

\section{Bhanji Gokul Parekh}

Bhanji Gokul Parekh provided the first ever translation proper of Julius Caesar in 1874. Not much is known about him except what is mentioned in the translation preface itself.

As the text and the preface indicate, he was a Principal of Anglo-vernacular School at Vala, near Vallabhipur in Gujarat. However, the translation did not occur at Vala. He was on leave for 20 days and visited Rajkot. While in Rajkot, he was wondering how he could spend his time meaningfully. He wanted to spend his time on something that delights as well as preaches values. This is how by "divine intervention" he turned towards the translation of Shakespeare's Julius Caesar. But before the translation gets published, he wanted to find out if the translation is likely to become "popular" or not. Hence, he called a meeting of like-minded scholars wherein he read aloud the first act of the translation. Some complained that the language of the translation is highly sanskritised. Instead of modifying it, he argued in the preface that Gujarati is derived from Sanskrit and there's no harm if it is sanskritised.

Interestingly enough, the verse portion of the translation was done by Balwantrai Ramchandra Junnarkar. He was perhaps a 
Marathi who somehow happened to be in Rajkot at that time. Not much has been mentioned about him anywhere in the translation. The translation was printed in Kathiawad Printing Press at Rajkot.

Translations don't occur in vacuum because it requires resources and patronage to get them published. There's a hint of how this particular translation was supported in the first few pages. To start with, the translation is dedicated to W. W. Anderson, the then Political Agent. It is easy to guess how Bhanji Parekh must have received some sort of support from him in order to get it published.

There are others who placed an advanced order to purchase multiple copies of the translation and lent a helping hand. In this list, His Excellency Mansinh, ruler of Dhrangadhra, a Princely State, purchased 35 copies of the translation. Keshavrao, the brother of Junnarkar, purchased 5 copies. Likewise, there are 9 other Marathis who purchased copies of the translation. It would be interesting to find out how these Marathis and one Gujarati made the first translation of a Shakespearean play happen way back in 1974. Nonetheless, it is easy to discern that Bhanji Parekh was well-connected with a variety of powerful people in and around Rajkot and hence, it was possible for him to draw the support of such diverse stakeholders. In any case, reconstructing the life and work of Bhanji Parekh remains an unfinished task as there's hardly any source of information other than the translation itself.

\section{Narbheshankar Pranjivan Dave}

Translation history surrounding Shakespeare's first few Gujarati translators is still an unfinished puzzle. While they are largely forgotten, they have left behind enough traces for us to recover the hidden treasures from the debris of history. 
But since translation discourse focuses entirely and exclusively on the text and leaves out the translator, the living, breathing human being, there is not much that is explored in terms of translator's life and work.

A popular version peddled by local historians that was accepted by all without a question was that Narbheshankar was a lecturer at Samaldas Arts College and he translated Shakespeare's plays. It is not a falsehood as the facts are correct independently; he served at Samaldas Arts College, Bhavnagar and he translated Shakespeare's plays into Gujarati. However, no one bothered to put together the chronology of his life's events.

Only after a recent exploration, it was brought to light that Narbheshankar's translation of Shakespeare's Othello and Julius Caesar came out in 1898 well before he even enrolled in Samaldas Arts College as an undergraduate student in 1899. He went on to complete his MA in Philosophy from Deccan College, Pune and later joined Samaldas Arts College as a lecturer in 1905.

The subsequent question that arises is that if he took admission in Samaldas Arts College in 1899 right after his Matriculation, was he 15 years old while he sat down to translate Julius Caesar and Othello into Gujarati in 1898 ?

It is only when one tries to reconstruct his life way back from his birth to his work that one can discover that he was born in 1870 and failed in Matriculation exam in 1885. Subsequently, due to familial compulsions, he takes up a job in railways near Veraval and keeps changing jobs till 1890. In 1890, he passes Matriculation exam and continues his miscellaneous jobs. It is only in 1899 that he enrols in Samaldas Arts College. The questions that we still don't know the answers about: 
- He was born in Chuda, near Surendranagar. How did he land in Bhavnagar?

- What did he do to survive during those years of struggle? How did he sustain his interest in literature?

- How did a student who failed in Matriculation get motivated to first of all read and then translate Shakespeare's plays into Gujarati?

- How did he earn the attention of the Princely State of Bhavnagar that he got the funding for 'Shakespeare Series' the translation of 6 Shakespearean plays namely Othello, Venis no Habsi (1898), Julius Caesar (1898), Measure for Measure (1905), The Merchant of Venice (1911) and Hamlet (1917) into Gujarati?

Narbheshankar Pranjivan Dave, 'Kathiawadi' survives today only in the form of his translations of Shakespeare's plays. His life is as much a mystery till date.

\section{Mohamed Rupani}

Mohamed Rupani (1912-2016) translated Shakespeare's 159 sonnets (1977), As You Like it as Aapni Pasandagi (1979), and published two volumes of translation of English poetry titled Angla-Kavya-Darpan Vol I (1999) \& II (2000). Rupani was born in Inhabane, Mtamba, Mozambique in 1912 and came to Kodinar, Gujarat, India in 1923 to acquire education. His father Juma Premji Rupani had immigrated to South Africa at the age of 14 to settle in Mozambique but he brings his children back to India and decides to settle down in Kodinar, Gujarat so that they can be properly educated. Rupani received primary education in the following way:

- Primary level education at a vernacular school in Kodinar 
- Junior high-school education, first year of English at H. H. The Aga Khan Boys School, Mumbai

- High school education, second and third-year English at an Anglo-vernacular school, Kodinar

His studies were interrupted in 1928 when he had to return to Ihambane. He stayed there till 1931. During this period, he explored his father's rich library and read Gita, Quran, The Bible etc. and developed his inclination into reading. His father, although barely educated, had written two books titled, Hind ane Africa no Vepar (Trade between India and Africa) and Aga Khan Hirak Mahotsav Granth (Diamond Jubilee Book).

While staying in Ihambane, he desired to pursue his studies but it was not possible. His mother suggested an alternative which was to start a business and offered a bag full of diamonds, jewellery and money. This was her effort to urge him to continue to stay there. However, Rupani declined it and returned to India to resume his studies. Upon his return to India, he attended Baroda high school during 1931-34 and Baroda College, later renamed as the MS University, Baroda during 1934-38 and graduated from Bombay University in 1939. He met Ms. Dilawer K. Kavi, the first Muslim student to enter Baroda College in 1936 and got married to her in 1940. Both shifted to East Africa in 1940 and taught in schools in Zanzibar (1940-41), Dodoma (1942-49) and Mombasa (194968).

Post retirement, they lived in Nairobi (1968), Ahmedabad (1968-70), Nairobi (1970-75), Ahmedabad (1975-88), Nairobi (1988-96), Porbandar (1996), Rajkot (1996-2000) and Jamnagar (2000-06). In 2006, Mr. and Mrs. Rupani shifted to Dignity Lifestyle Retirement Township, Neral. Mrs. Rupani passed away on December 14, 2006 at the age of 89. Rupani then shifted to Swami Ramanand Shastri Senior Citizens 
Home, Lonavala in 2009. In 2013, he shifted to Janseva Foundation's Old Age Home near Pune and passed away there in 2016.

In all, this is the 104-year long journey of Mohamed Rupani's life from 1912 to 2016. It is fascinating story as a whole. From the point of view of translation history, the following questions arise:

- For someone who worked, lived and retired in South Africa, how did he first of all keep his language skills proficient enough to embark upon translations?

- After retirement in 1968 and return to Gujarat in 1975, how did he think of translating Shakespeare's 159 sonnets and As You Like It? He came to Ahmedabad only in 1975. How did he get the two translations published so quickly in 1977 and 1979 respectively?

- Was this his first effort of translation? Apparently, his only other work of translation of English poetry gets published in 1999 and 2000.

- How did he manage to find a publisher in a region wherein he had not lived for the most part of his life? How did he manage to get every known scholar of the day to comment on and review the translations?

- After returning to Gujarat in 1975, why did he live at these different places for the next 35 years or so?

Some of the possible explanations are as follows: First of all, his preface to his translation of Shakespeare's Sonnets or As You Like It does not provide any clue to his initiation into translation or where the motivation came from. However, the preface to Angla-Kavya-Darpan provides some insights which throw light if properly correlated and analyzed. To start with, he shares his memories of Baroda College during 1934-38 and shares how his teachers introduced him to English poetry and 
how he used to be mesmerized by the lectures delivered by his teachers related to English poetry (XVII). He mentions how the study of Shelley and Keats transported him in another world altogether in the first year itself. Prof. Romans taught English Prosody which served as the foundation of his translation of Shakespeare's sonnets and poems contained in Angla-Kavya-Darpan. While Rupani was keen to write poetry in English, Prof. Romans motivated him to try and write poems in Gujarati. This was a turning point for Rupani because he began to write poems in Gujarati and his first ever publication is his collection of original poems in Gujarati titled Yogini Mari (1969) well before the translations. Once he was motivated to write in Gujarati, it is logical that he was drawn towards studying the existing Gujarati and English poetry. It was evident that he found English poetry superior and eventually decided to introduce the Gujarati readership with the very best of English poetry and literature.

In addition, it is interesting how he got the two volumes of translation of English poetry titled Angla-Kavya-Darpan in 1999 and 2000 as the last publication but it was the first effort as far as translation is concerned. His preface to Angla-KavyaDarpan mentions how he began to translate English lyric poetry into Gujarati since 1939. He states beyond doubt that he continued to revise and improve his translation of English poetry for 6 long decades from 1939 to 1999 before finally getting it published in 1999 (XI). Therefore, it is an eyeopening study of apparent chronology of his publication of translation of Shakespeare's 159 Sonnets, As You Like It and Angla-Kavya-Darpan is 1977, 1979 and 1999 respectively. So, it can mislead into thinking that he translated sonnets first, followed by As You Like It and lastly the English poetry after 20 years or so in 1999. However, only the close study of a translator's life, his/her journey and evolution as a translator can explain the true chronology and true history of the events 
as they unfolded. In no small way, the study of Mohamed Rupani's life is the only way to explain the history that surrounds his translations.

While translation has emerged as almost a discipline in itself, the funds, grants, projects and doctoral work have grown in the last 20-30 years in Gujarat, it is unfortunate that a devoted translator such as Rupani who translated for 6 decades of his life lived and died in complete anonymity as far as translation researchers and historians are concerned. The fact that Rupani struggled hard to find a publisher for Angla-Kavya-Darpan and eventually published it all by himself should not be lost in this debate on translation history and how we should go about it.

A study of a translator in the entirety of his/her life and work is also essential to comprehend the full import of his/her contribution as a translator. For instance, when you study Mansukhlal Jhaveri as a translator of Hamlet and Othello, it is an incomplete narrative. $\mathrm{He}$ is an extraordinary instance in translation history and deserves a unique place in translation history because he is arguably the only Gujarati translator who translated the plays of Kalidas and Shakespeare both. A comprehensive study of this sort can place a translator in history and provide us with a richer history than what we would have if we consider his translations of Shakespeare's plays alone.

His evolution as a translator anyway deserves a detailed analysis of his life purely because of his journey starting from Jamnagar to studies at Samaldas Arts College, Bhavnagar and eventually landing in Mumbai. During this journey, how did he develop as a translator of texts of two of the greatest playwrights in the history of literature - Kalidas and Shakespeare? An explanation to this question would be 
incomplete without reconstructing his life and work in its entirety.

If translation history is all about reconstructing the historical context, how are we going to reconstruct it without the translator, with its chief protagonist missing from the narrative? How can we throw light on history without shedding some light on the translator who facilitates the cultural transfer of complex literary compositions? There is little that we can accomplish unless we get to reconstruct the life and work of the translator who shapes and is shaped by the obtaining world around him, is swayed by different cultural forces and is moulded by motivations of different sorts.

As Anthony Pym (1998: 30) famously said, "study the translator first, then the translation"

\section{Selection of the Text for Translation}

It would be naïve to think that translators randomly select the text without any rhyme or reason. Such a belief would only perpetuate a theory of chaos when it comes to translation history. Selection by nature is political. There's always some or the other compelling reason why people select what they do. The same holds true for translators. In this element of choice, we can discover nuances of translation history if we pay our sincere attention. As D'hust (2010) puts it:

What has been translated? And what not? In other terms: what have been the selection procedures used (and also according to what underlying criteria?) To answer such questions, the establishment is needed of bibliographies of translations, and eventually of what could have been translated, but was not (25).

The present model of historiography in India, if there's such a thing, is content to report who translated what and leave it at that. It is assumed that he/she translated it out of a Good 
Samaritan's spirit and the translator simply randomly selected the text without much of a prior thought.

Such historiography furthers the idea of randomness in the wake of such a practice. It strengthens the philosophy that translators are acting out of their will and volition all the time. They select text randomly or impulsively and translate according to some whim or fancy.

However, those who understand the nature of history will not be content with 'who' and 'what' and will want to raise the more fundamental historical question 'why'. The reason for raising such a fundamental question is to uncover new facts and interpretations of such translator choices in terms of selection of texts. As Venuti (1995) says in Translation, Community, Utopia:

The inscription begins with the very choice of a text for translation, always a very selective, densely motivated choice, and continues in the development of discursive strategies to translate it, always a choice of certain domestic discourses over others (468).

In the context of the power relations which are at work between the translator and his patrons and publishers, can we afford to consider the selection of the text as an innocent process? Can we indulge in make-belief that the translator had innocently engaged in the random selection of a text? By nature, choices, if not always political, are always conscious and purposeful. Here're a few interesting cases of selection of text for translation:

The case of Narbheshankar Pranjivan Dave makes an intriguing study. For someone who was struggling to make two ends meet and for which he had to take up and switch petty jobs from 1885 to 1898 , how could he take up Shakespeare's 
plays out of his will and volition to translate them into Gujarati? Narbheshankar who could barely manage to pass his Matriculation after two attempts was naturally more worried about putting food on the table for his family than translating Shakespeare. How, all of a sudden, he gets interested in translation of none other than Shakespeare's plays? One can understand his inclination towards translation, but the question still remains, why Shakespeare?

It is only when one relates the patronage that he received from the Princely State that one could possibly piece together some sort of explanation of his selection of the text. We may or may not be able to explain why the Princely State wanted Shakespeare's plays translated into Gujarati but at least we would be clear about the fact that Narbheshankar did not make such a choice because he was acting under the instructions of the State and his further education and subsequent employment stemmed from his translation project funded by the State.

\section{2}

Mansukhlal Jhaveri (1907-1981) translated three of Shakespeare's plays namely Hamlet (1967), Othello (1978) and King Lear (1983). The question to be asked is why he chose to translate Shakespeare's plays in the first place. The other question is the choice of the plays for translation. For Hamlet, we may not be able to find any immediate reason for selection. But Othello's Gujarati translation carries a preface by Umashankar Joshi, the renowned poet, critic and translator. In it, Joshi explains that it was he who asked Jhaveri to translate Shakespeare's Othello. If we don't raise the question of the selection of the text, we would never uncover the role Joshi played in getting Othello translated into Gujarati. The subsequent question as to why Joshi wanted Jhaveri to translate Othello into Gujarati also reveals some useful insight. Joshi had conceptualized a series of 15 translations under 
Kavita Sangam: Nisheeth Puraskar Granth Mala - 22 published by Gangotri Trust established by Joshi himself. All the other texts were poetry from Indian and other languages translated into Gujarati. Among these, Joshi wanted to get Shakespeare's Othello translated which is why he requested Jhaveri for the same.

The Joshi-Jhaveri collaboration was not random either. They were in touch with each other for years and two volumes of Joshi's letters include letters which refer to their collaboration and association. This was no random act of translation of a random text. It was a part of a larger translation project including 22 texts and Joshi gets Jhaveri to contribute a translation and it happens to be Othello. It was followed by a translation of King Lear in 1983. So, it was Joshi's selection of the text that led to the translation of Othello and King Lear into Gujarati. Joshi also selected the translator for the text in the form of Jhaveri. In this way, Joshi made his lasting contribution to translation history by getting this text translated.

\section{3}

Hansa Mehta, the first Vice Chancellor of MS University, Baroda, translated Shakespeare's Hamlet (1942) and The Merchant of Venice (1944) into Gujarati. It would be pertinent to bear in mind that she played many roles in her life as a reformer, social activist, educator, and she also translated Shakespeare's plays. As a translator, she comes across as quite eclectic as she translated into Gujarati eight cantos of Valmiki's Ramayana, Moilerena be Natako (Tortuffe and Le Bourgeois Gentilhomme, two of Moliere's plays in French), and Jonathan Swift's Gulliver's Travels. The question that arises is how did she and why did she choose Shakespeare's plays for translation? Explaining the motives and inclinations of a translator is an integral part of a translation historian's 
assignment because it is, at times, the motives and inclinations that shape the translation and consequently the translation history.

Hansa Mehta explains it in her preface to the first translation how and why she decided to translate Shakespeare's plays into Gujarati. In the preface to the translation of Hamlet, she mentions how B. K. Thakore, the renowned poet, pointed out that the leading Gujarati poets have not translated Shakespeare's plays. She also goes on to quote R. V. Pathak, the noted critic, who makes the scathing remark that our young Gujarati writers indulge in the translation of trash stories but do little to render Shakespeare's plays into Gujarati. Mehta further states that when she read this line from Pathak, it deeply stung her heart and she resolved to translate Shakespeare's play.

In the preface to the translation of The Merchant of Venice, she states that B. K. Thakore expected me to translate one more Shakespearean play. She goes on to explain that since Hamlet was a tragedy, she decided to choose The Merchant of Venice which is a comedy. One would find it hard to grapple with the logic of choosing one tragedy and one comedy for being opposite forms of dramaturgy. However, translating one more play was not a part of her plan; it was B. K. Thakore's expectation that she sought to fulfill by translating The Merchant of Venice.

\section{4}

In an interesting aside, it is fascinating to study what does NOT get translated and what is NOT selected for translation. For instance, the way Gujarati translators showed sheer disregard for Shakespeare's comedies demands to be studied because it is baffling as to why most of them would engage with tragedies alone and disregard comedies. Each Gujarati translator was unique but what was common among them all 
was that each one believed that Shakespeare was a great playwright and his plays need to be translated into Gujarati. However, the neglect towards the same dramatist's comedies is perplexing, to the say the least.

In other words, if translators believed that Shakespeare's comedies were far more creative and richer, generation by generation, they would translate them and more importantly they would translate them again and again. However, the history related to the selection of texts for translation seems to indicate the opposite. So, when one searches for how many of Shakespeare's comedies got translated and how many times, it provides important insights in terms of selection of text in translation history. Shakespeare's comedies did not attract Gujarati translators for some mysterious reason and that is why barring a couple of translations, Shakespeare's comedies remained untouched by Shakespeare's Gujarati translators. It would be pertinent to compare this with those who did not translate but adapted Shakespeare's plays into Gujarati. C. C. Mehta adapted A Midsummer Night's Dream, Aapabhai Patel adapted As You Like It, and not to mention the Parasi theatre groups who thrived mostly on Shakespeare's comedies earlier in history. A study of selection and exclusion of texts is a rich site of new insights into translation history and shed new light on how Gujarati translators approached Shakespeare's plays.

This leads one to wonder whether translators carry out their noble duty of facilitating the cultural transfer in the best interests of the humanity or they are motivated by other factors as well. It is a legitimate concern whether translators are always motivated by genuine duty of ushering in the best of texts into their mother tongue or there are other motivations at work. In any case, one can no longer assume that the selection of texts is random. It would also be erroneous to assume that the translators select the text based on the merit of the text 
because they tend to select the text it in spite of its apparent lack as well. They may also exclude texts in spite of apparent merit. Moreover, it is misleading to think that translators are individuals who are on a mission and objectively select the texts. It is in their subjectivity that we can unearth new interpretations related to the history and the context of their translations.

\section{Poetics}

It is old-fashioned now to think that translators always adhere to the original and remain loyal to the text while translating. It's high time we paid more attention to the poetics of the translation to discover valuable insights regarding the translation history. The way a translator goes about translating a text tells a story. Contrary to popular belief that translators translate in a particular reason without any agenda, there's always a reason why a translator would translate in a particular way. Venuti (1995) articulates it quite succinctly:

Translation never communicates in an untroubled fashion because the translator negotiates the linguistic and cultural differences of the foreign text by reducing them and supplying another set of differences, basically domestic, drawn from the receiving language and culture to enable the foreign to be received there. The foreign text, then, is not so much communicated as inscribed with domestic intelligibilities and interests (468).

As far as translation history is concerned, the poetics of translation is also an equally important site for investigation. If the selection of a text is not random, how can the literary choices and strategies be random? The way translation is approached and carried out cannot be deemed random because there are multiple translations of the same text and respective translators have translated the same text in different ways. 
Each translator perceives translation differently and consequently approaches translation differently.

It is necessary to understand the translator's perception of translation as a process so that we can understand his/her translation strategies and choices. In the $11^{\text {th }}$ Gujarati Sahitya Parishad Meet at Lathi, in 1933, Mansukhlal Jhaveri delivered a discourse on "Bhashantar Karvani Kala" ("The Art of Translation"). Regarding the definition of terms, Jhaveri asserts:

Bhashantar (literal translation) and Anuvad
(Translation Proper) are not synonyms. The
difference between Bhashantar and Anuvad is the
same that exists between a photograph and an oil
painting. In the first, the outline of the original will be
mostly accurate but the beauty of form and colours
cannot be faithfully reflected. In an oil painting, both
can be captured; the outline may vary a little.
However, the painter of an oil painting will employ
his imagination in some way and strive to render it
closer to the original. Skill is required in both the
things (526).

It is safe to infer that Jhaveri must have tried to provide an Anuvad of Hamlet into Gujarati and hence, the poetics would completely change, compared to translator such as Narbhshankar Pranjivan Dave who practiced Bhashantar or literal translation. Here's a different perspective from Mohamed Rupani who says that "like an actor of the theatre, the translator transcreating a work plays the role of the original poet; it is not merely a Bhashantar or Anuvad. The entire form, body, soul, heart, mind and everything else gets embedded in it (1).

On the other hand, Jayant Patel avers in an email interview that he "translated Shakespeare's plays exclusively to help my 
students, who needed to be aided in grasping the gist of the classics that they were struggling to fathom. The 4 plays I selected were the required textbooks at that time" (3).

As it is evident, each translator thought differently about the task of translation and hence went about it in a different way. Partly, these different ways emanate from their desire to render a text as well as they can and on the other hand, make it more palatable to the readership.

Unless we rigorously scrutinize the translations in terms of their literary aspects, we would never be able to throw light on why translations exist in the form that they do. The way a translation exists in its literary sense depends on a set of choices that the concerned translator makes in terms of form, style, simplicity or obscurity of language etc. based on the objectives of translation. Either the translator decides and defines the objectives or it is the Patron/s who determine(s) the objectives of translation which eventually dictate the poetics of the translation. Here're a couple of case studies:

\section{Multiple Translations of the Same Text}

\section{Hamlet}

Narbheshankar Pranjivan Dave, Hansa Mehta and Mansukhlal Jhaveri translated Hamlet into Gujarati in 1917, 1944 and 1967 respectively. In this particular instance of multiple translations of Hamlet, Narbheshankar Pranjivan Dave's translation of Hamlet is a prose translation and Hansa Mehta's translation of Hamlet is in Anushtup metre.

If one studies how each translator translates the soliloquy "To be, or not to be, that is the question", it is possible to infer a few interesting insights. Shakespeare does not use any adjective for the "question" in order to explain how the question is so profound or painful to deal with. He simply uses the definite article "the" and conveys that this is the most 
profound question. Now when one reads the translation of the line "that is the question" in the above mentioned three translators' rendering, it is evidently clear how each one did it differently and reasons for these different ways of translation are also more or less clear.

Hansa Mehta translates "that is the question" as "that is the big/great question". She adds the adjective perhaps to intensify the effect of the line. Mansukhlal Jhaveri translates it as "that is the question of all questions"! He also tries to add to the impact of this line by elevating it to the status of the crowing question among all the questions! On the other hand, Dave remains faithful to Shakespeare's wordings "that is the question" and renders it as "that is the question" in Gujarati. (Translation mine) That is not enough. He goes on to provide a foot-note to "To be, or not to be, that is the question" and explains what Shakespeare's intended meaning is.

In Dave's case, the objective of the translation is what guides and shapes his translation. He (Dave: 02) describes his objective as follows:

With an objective of introducing Shakespeare's plays in their original form to the Gujarati community, however difficult that may be, I have undertaken the task of translating the same into Gujarati....Following this objective, I have adopted the method of literal translation in this task (Translation mine).

Such an objective also explains why all of Dave's translations carry copious foot-notes as well. The translation is also preceded by unduly long introduction containing explanations regarding Shakespeare's plays, his art and the views of several critics.

On the other hand, Hansa Mehta translated the concerned line with quite a different objective. In the light of the observations 
by B. K. Thakore and R. V. Pathak that no Gujarati poet had attempted to translate Shakespeare's plays in verse, she wanted to change this and attempt a Gujarati translation of Shakespeare's plays in verse. She frankly admits how it stung her in her translator's preface and which made her undertake the translation. For translating Shakespeare's Hamlet, she uses a metre called Anushtup. Therefore, her objective was to ensure that he provides a translation of Shakespeare's plays in verse using Anushtup, however difficult that may be. It is possible that she faced some difficulty in rendering the line and fitting it in the metrical scheme of Anushtup. Since she used this particular metre, she seems to have received some criticism as well because she responds to the criticism for her translation of Hamlet published in 1942 in the preface to the translation of The Merchant of Venice in 1944. Her response is regarding whether an adequate translation of Shakespeare's plays in verse is possible or not and whether the use of Anushtup as a metre is appropriate, as she (1942: 02) writes:

Like Hamlet, this play is also rendered in unrestrained Anushtup. At places, I have also used other metres as well. Whatever critics' observations regarding Hamlet's translation that I came across, I found them quite shallow... One section of critics has made up their mind that Shakespeare's plays cannot be translated in verse. The other section thinks that verse translations are possible but Anushtup is not the right metre for it. Before long, I have admitted that it is not possible to transfer the exact quality of the original into the translation, whether it is a translation in Gujarati or any other translation (Translation mine).

As it is obvious, she had her tough moments as a translator using Anushtup metre. However, it is not clear as to why she would translate the line so very differently into Gujarati from 
the line in the source text. Consider the source text and the translation as follows:

Shakespeare: "To be, or not to be, that is the question"

Hansa Mehta: "To live? To Die? That one big question, agonizes me" (Translation mine)

Now this "agonises me" is not a part of the source text other than the fact that the whole soliloquy is a poignant expression of agony. Why would Mehta go to the extent of adding words/phrase to extend the line from the source text in her translation? Why would she add words that don't make any substantial contribution to the meaning of the line? Was it because she wanted to clarify how "it agonizes" Hamlet? Or was it because she was using a metre that necessitated such a measure? There are no easy or ready answers to the way Mehta translated the Shakespearean line in the way she did. It would only be possible if further research into translation history related to Hansa Mehta's translations leads to the recovery of her letters or any other documents explaining how and why she went about translating Shakespeare in this particular way.

One can compare the multiple translations of the entire soliloquy rendered by the three translators but it would probably translate into an independent area of study. However, one thing is amply clear that multiple translations of the same text, when read together along with the historical and personal context of the translator in view, can shed new light on the way translations were approached and carried out.

\section{The Merchant of Venice}

Shakespeare's The Merchant of Venice was the oft-translated play among all of Shakespeare's plays into Gujarati. Each translator used the same Gujarati title for the play as Venis no Vepari. 
Here're the translators who translated The Merchant of Venice into Gujarati and the chronology of the translations:

\begin{tabular}{|l|l|c|}
\hline $\begin{array}{l}\text { Sr. } \\
\text { No. }\end{array}$ & \multicolumn{1}{|c|}{ Translator } & $\begin{array}{c}\text { Year of } \\
\text { Translation/Publication }\end{array}$ \\
\hline 1 & Narbheshankar Pranjivan Dave & 1911 \\
\hline 2 & Hansa Mehta & 1944 \\
\hline 3 & Jayant Patel & 1964 \\
\hline 4 & $\begin{array}{l}\text { Krushnashankar Ambashankar } \\
\text { Vyas }\end{array}$ & 1975 \\
\hline
\end{tabular}

How each translator translated the play throws ample light on how translation does not exist in vacuum and it has a context within which it needs to approached and understood. Each translator mentioned above had related to his/her historical context and worked out a suitable strategy for translation in consonance with the same. In order to understand the translation, one needs to study the strategies employed by the translators and more importantly why they worked out the strategies that they did and see if there's any correlation exists among them.

According to those who believe that these translations were all random tend to assume that these translations existed independent of one another and each translator was working without any particular objective or agenda. Randomness also suggests that there was no correlation between one translation and the other. What if these translators took into consideration the previous translations and carried translation history in the way they were translated?

Here's a particular strategy that each of these translators consciously used with a sense of history:

If there was one translation concern commonly shared by these four translators, it was the conscious choice of form for their 
respective translations. Here's the choice each translator made in terms of form.

\begin{tabular}{|c|c|c|}
\hline $\begin{array}{l}\text { Sr. } \\
\text { No. }\end{array}$ & Translator & $\begin{array}{c}\text { Type/mode of } \\
\text { Translation }\end{array}$ \\
\hline 1 & $\begin{array}{ll}\text { Narbheshankar } & \text { Pranjivan } \\
\text { Dave } & \end{array}$ & Prose translation \\
\hline 2 & Hansa Mehta & Verse Translation \\
\hline 3 & Jayant Patel & Prose Translation \\
\hline 4 & $\begin{array}{l}\text { Krushnashankar Ambashankar } \\
\text { Vyas }\end{array}$ & $\begin{array}{l}\text { Gadhyapadhyatmak } \\
\text { Translation- it is a } \\
\text { translation that is in } \\
\text { prose but carries the } \\
\text { rhythm of verse. }\end{array}$ \\
\hline
\end{tabular}

As mentioned earlier, Dave was clear about the objective of the translation he was attempting. Either the translator or the Princely State had made the choice to make the translations accessible to the masses. Therefore, the strategy that Dave adopted was to make the translations as 'literal' as possible. This would have been impossible if he were to render the play in verse. So, providing translations in prose was a strategy closely aligned with the larger goal of making the translations accessible.

In the case of Hansa Mehta, it was clear that she was filling the historical void with her verse translations. As mentioned earlier, she decided to translate Shakespeare's plays primarily because eminent critics and scholars such as B. K. Thakore and R. V. Pathak had pointed out how major poets of Gujarati have stayed away from translating Shakespeare in verse. Mehta took up the task of translating Shakespeare basically to render them in verse. In fact, to be precise, Mehta seems to suggest that after her translation of Hamlet, she has already addressed the issue but since Thakore suggested Mehta should 
translate one more Shakespeare's play into Gujarati. That is the reason why she attempts the second translation.

In any case, since the translations done by Dave already existed in prose that Thakore refers to and uses the said translation to put Mehta's translation in perspective. He goes on to ask the readers to compare translations done by Dave and Mehta so that readers can fully appreciate the worth of Mehta's translation. Thakore personally knew Dave also because he was Thakore's "student at Deccan College, Pune" (02). While most translation historians have missed it, it is necessary to remember that Thakore was the connecting link to both the translations. Since Thakore knew Dave and his translation, while he comments on Mehta's translation, he keeps in mind Dave's translation in prose. In any case, it is clear that Thakore and Mehta were aware that Dave's Gujarati translation of Hamlet, although in prose, exists. Why would one want to translate a text for which a translation already exists? It is easy to infer that translation was not the true objective. To set the history right, it is necessary to point out that Mehta's objective was not to provide the translations which have not been attempted so far. In fact, the objective was to provide verse translation of Shakespeare's plays. Hence, in Mehta's case, providing a translation was secondary but the form was primary. It is necessary to pause and ponder over the fact that if we take satisfaction in translation history that only documents the chronology of Dave's and Mehta's translations as independent attempts unrelated to each other, we would miss the crucial aspect of how Mehta had the awareness of history and acted in accordance with the concerns that such a history gave rise to. She translated in order to provide verse translation of Shakespeare's plays. What apparently seems random as the decision of the translator was a carefully thought out decision and there was nothing random about it. In 
the end, such a decision shaped the translation as it exists today in verse form.

In the case of Jayant Patel, he probably had a completely different context in which he went about his translations. However, there's evidence to suggest in his preface to the translation that he first brought out prose translation of Othello in Gujarati for "his friends and general readership". Once it was received well, he was inspired to attempt the prose translation of The Merchant of Venice in the same vein. This is the reason why he goes ahead and provides the translation of Shakespeare's four plays in prose including The Merchant of Venice. The reason why attempted a prose translation was that he was translating it for "friends and general readership" and not to respond to the observations of eminent critics such as B. K. Thakore or Pathak. He had no reason to use verse form or make the translation scholarly in any way.

It is dangerous to guess why a translator adopted a particular strategy. Therefore, it is necessary at times to refer to different sources available to the translation historian such as the translator's preface, letters, memoirs, autobiography etc. and ascertain why he/she chose such a strategy. If the translator is alive, it would be better to locate the translator and interact with him/her and find out the authentic explanation from $\mathrm{him} / \mathrm{her}$. In this case, it was possible to connect with Jayant Patel who is currently based in the US.

In a telephonic conversation, Patel conveyed to the researcher that he had done the translation for his students of Bachelor of Arts and Master of Arts in order to introduce them to Shakespeare's plays. Since the students had Gujarati as a major, it would not be easy for them to appreciate Shakespeare's plays in English. Therefore, Patel, a lecturer in Gujarati at MTB Arts College, took the initiative and translated Othello into Gujarati for his students of BA and MA. 
In the preface to the translation of The Merchant of Venice, he notes that it was because the first translation was received well by his students, he was inspired to continue and so he went on to translate The Merchant of Venice into Gujarati. Now it makes perfect sense why he chose to make it a prose translation. Since he was translating for the readership consisting of undergraduate and post-graduate students who would prefer a translation that is easy to understand, he consciously decided to opt for a prose translation. One can easily deduce that he must have deliberately kept the style and language simple as well in order to ensure that the students can readily understand and appreciate Shakespeare's plays. In any case, he turned the clock back and went back to previous mode of prose translation attempted by Dave.

However, it was Krushnashankar Ambashankar Vyas who improvised and provided the translation that falls in neither category of prose or verse translation. He devises a prose translation that carries the rhythm of verse. This was not random either. He was aware of previous translators' work and their strategy. He mentions in his preface that Hansa Mehta has published a few translations. Some lecturer in MTB Arts College at Surat has also attempted a few. However, he decided to use a strategy different from his predecessors as he states in his preface. His preface to the translation is a statement on translation history itself. He states:

But I am not aware of a Gadhyapadhyatmak translation (prose translation that carries the rhythm similar to verse). As a result, the literarily inclined readership in Gujarat is not able to fully relish Shakespeare's plays. I have felt this for a long time that Gujarati literature would also become richer if we could take care of this inadequacy. Therefore, I translated The Merchant of Venice in 
Gadhyapadhyatmak form in around 1963-64 (1) (Translation Mine).

It is the succinct possible statement of translation history that contains the chronology of all preceding translations, and the rationale and strategy for his translation- all rolled into one!

When one studies the translation strategies and choices executed by translators, it is possible to learn more about the translation history that preceded and followed each translation. It is also possible then to construct the organic development of translation in the given historical context.

\section{Interventions and Support Mechanisms - Fellow Writers / Translation Scholars}

The historiography that assumes that translators are all independent and function on their own do not really understand the true, collaborative way in which translators work. In other words, translators hardly work either entirely on their own or alone. If historiography fails to shed some light on the part played by other writers and scholars who aided the translator in question, the translation history that we will have will not only be flawed but it will complete erase the contribution of scholars and writers who went out of their way to make translations happen in the first place. In the case of Shakespeare's plays translated into Gujarati, it is no different. Shakespeare's Gujarati translators hardly worked alone. They had their mentors, unofficial co-translators, part-translators and reviewers who intervened and made their contribution as and when required at the suitable stage of the translation process. Here are a few cases of Gujarati translators receiving support from translation scholars:

Umashankar Joshi's contribution to the translation of Shakespeare's plays into Gujarati is little known. He 
contributed to the translations in salient ways. In the case of Nalin Rawal's Gujarati translation of Shakespeare's The Tempest, the translator's preface mentions that it was Umashankar Joshi who asked him to translate the said text. Rawal also goes on record to state that Joshi had carried out what he calls 'co-reading' of the translation with Rawal. Rawal further states that Joshi made several important suggestions for the improvement of the translation. Since the basic historical question is 'why', it was necessary to discover as to 'why' Joshi wanted Rawal to translate Shakespeare's play. Therefore, it was necessary to investigate into it for some plausible reason for the same. Fortunately, instead of consulting any other sources, it was possible to get in touch with the translator himself for the answer. In a telephonic conversation with the researcher, Rawal explained why Joshi asked him to translate Shakespeare's The Tempest. Prior to the translation, Rawal had written an article on Shakespeare in a Gujarati literary magazine called Kavita edited by Harindra Dave, the renowned Gujarati poet. It was after reading the article in Kavita that Joshi reached out to Rawal and asked him to translate The Tempest.

In the preface to the translation of Othello, Joshi mentions that he requested Mansukhlal Jhaveri to translate Othello into Gujarati for Kavita Sangam: Nishith Puraskar Granthmala 15, a collection of 15 translations by different translators. The question to be asked is why Umashankar Joshi asked Jhaveri and not any other translator to translate first Othello and later King Lear into Gujarati. In his own words, Joshi says about Jhaveri in Isamu Shidaane Anya:

His translation of Shakuntal is quite readable but I have no hesitation in stating that his translations of Shakespeare's plays are the best translations of Shakespeare of all times. His translation of Hamlet 
was received very well. When it was published, I had requested him to translate as many Shakespeare's plays as he can. He translated Othello into Gujarati. In it, the way Iago deceives Othello- changes the way Othello thinks about Desdemona and the scene wherein Othello kills Desdemona- when we read it in Gujarati prose, in Mansukhlal's prose, we hear Shakespeare's voice in it (158) (Translation mine).

It is an excerpt from an article titled "Mansukhbhai" which does not even mention the last name "Jhaveri" in the title. This goes on to show that there was one and only one "Mansukhbhai".

Jhaveri also acknowledges the same in the preface to his translation of King Lear published in 1983. He says:

The true credit for the rare good fortune of ushering in the translation of Shakespeare's third tragedy into Gujarati is accorded to me should actually go to Umashankar Joshi. After going through my translation of Hamlet, if he had not written to me, "Please translate as many of Shakespeare's plays as you can", I would not have turned towards Othello and King Lear (i).

While Jhaveri did not live long enough to see the publication of King Lear but he shared with Joshi that "The moments I have spent in translating these two plays (Othello and King Lear) are the best moments of my life- that is the kind of bliss that I have experienced in these translations" (158).

Thus, Umashankar Joshi played a crucial role in facilitating these translations and ensuring that we get "the best translations ever" of Shakespeare's plays. He influenced the translation history by directly intervening in order to get the two plays translated into Gujarati. A translation history that 
disregards the intervention by Joshi will fail to register the blessing that Joshi turned out to be for translation as well as Jhaveri - who without Joshi would have been that much poorer in terms of translation.

\section{2}

Mohamed Rupani, the first and perhaps the only translator of Shakespeare's sonnets, relates a unique instance of how fellow translators and scholars helped in the process and publication of his translation of Shakespeare's sonnets. He lists them and mentions his interaction with them in a chronological order:

- When presented with the manuscript of translation of Shakespeare's sonnets, Mansukhlal Jhaveri recited a sample sonnet and guided him to avoid the imitation of English sonnet in the way it is recited. This must have helped Rupani to retain his original style in the way Rupani translated the sonnets into Gujarati. The interaction took place during February 14-21, 1975.

- Vishuprasad Trivedi (March 31, 1975), Suresh Dalal (April 11, 1975), and Umashankar Joshi (November $10,1975)$ went through the translation as per the time stamps mentioned in the bracket and made some suggestions to fine-tune the sonnets for final publication.

- Yashwant Shukla went through the translation during November 11, 1975 to January 1976 and provided his suggestions to improve it further.

- Pinakin Dave went through the translation on December 23, 1976 and Hasit Buch read the translation on May 05, 1977.

- Suresh Joshi went through the translation on April 29, 1977 and it was with the encouragement and motivation extended by Suresh Joshi that the Gujarati 
translation of Shakespeare's 159 sonnets finally got published.

While translating Shakespeare's Hamlet into Gujarati, Narbheshankar Pranjivan Dave asked his friend, scholar and translator, Keshav Harshad Dhruv to translate player's speech on the ransacking of Troy (2.2 474-541) into Harigeet metre.

\section{4}

In his preface to the Gujarati translation of Shakespeare's Richard III, Jashwant Thakar writes about how Santprasad Bhatt, the well-known Shakespeare scholar and professor of English, would remind him each and every time they would meet and insist upon the attending to pending translation of Richard III into Gujarati. Thakar frankly admits the gratitude towards Bhatt for the continuous insistence for the translation and performance of Richard III.

There are several such instances wherein fellow writers and scholars have helped, intervened and got the translation published. The question, however, is can we simply disregard the interventions and help provided by fellow writers and scholars in the process of carrying out and completing these translations of Shakespeare's plays and sonnets? Can we credit the translators and translators alone for accomplishing this? Wouldn't it be unfair to the translation history that we erase these interventions and disregard these contributions? Should we not take into account every aspect and factor associated with the act of translation no matter how small it may be so that we can put together a more comprehensive and honest account of translation history?

Historiography related to Shakespeare's translations into Gujarati would be incomplete without asking and addressing these questions and concerns. 
Sunil Sagar

\section{Patronage and Censorship}

If there were no power relations or any such complexities, there would be no reason to use different perspectives, consult archival resources and study diverse sources of information such as letters, biographies, memoirs of translators and other important figures of the age in which a particular translation occurs. Translations cannot be studied in isolation also because there may be factors which may influence the 'why', 'what', 'how', 'when' of translation history. Control mechanisms such as patronage and censorship which apply in literary works are equally relevant in translation history.

In today's world, there are numerous ways to get a work published. As we study the $19^{\text {th }}$ century and even parts of $20^{\text {th }}$ century history, there were fewer options for translators. One of them was rich individuals who had a certain liking for literature that would lead to the translation of certain kind of texts. Secondly, there were Princely States which had the resources to invest into literature and translation. Mohamed Rupani's case is an eye-opener as to how it was difficult to get a translation published for a translator. He translated Shakespeare's 159 Sonnets and got it reviewed by every known scholar of the day. The same is true about his AnglaKavya-Darpan. However, it is documented history that he could not find the publisher for his sonnets and Angla-KavyaDarpanin spite of desperate attempts. He went to the extent of shifting to Rajkot in order to get his Angla-Kavya-Darpan published. He approached every known agency that could publish it but it did not work out. While all this was happening, all he had was a shop for selling watches in Ahmedabad. Eventually, having been tired of these disappointments, he bore the burden of the publishing expense of both- the sonnets and Angla-Kavya-Darpan. On the brighter side, he could provide translations in the way he envisioned and faced no 
restrictions imposed upon him by a patron. Since the patron enables the publication, he/she instantly acquires certain power and privilege. He/she gets to decide quite a few things and shape the way translation eventually turns out.

To put it in perspective, Narbheshankar Pranjivan Dave's translation of Shakespeare's plays have little to do with the translator's missionary zeal for rendering Shakespeare into Gujarati but it has everything to do with the Princely State's perception of how translation was important and the reason why they chose to get Shakespeare's plays translated into Gujarati. The patronage that the Princely State of Bhavnagar extended to Dave is the sole reason why these translations took place in the first place. So, it answers the first question of 'why' these translations occurred in history. Not because Dave was on a mission but because the Princely State thought it was necessary to get Shakespeare's plays translated into Gujarati.

What gets translated and what doesn't is always a question worth exploring because it provides some insights into the way a translator went about his/her work in the given historical context. In this case, Shakespeare's plays get translated because the Princely State perhaps wanted it that way. For the Princely State of Bhavnagar, Shakespeare was not a stranger. Different theatre groups from Mumbai and Gujarat used to regularly come and perform at Bhavnagar during the second half of the $19^{\text {th }}$ century and it is obvious that Shakespeare's plays were performed as well. Jamshedji Unwala who was the Principal of the high school and a Professor at Samaldas Arts College at Bhavnagar was, once upon a time, also an amateur actor in a Parsi Theatre group in Mumbai. So, Shakespeare's plays getting translated is perhaps more logical in the context of the Princely State's liking for theatre and Shakespeare. This answers the question as to 'what' got translated in this case. 
If one studies Dave's translations in isolation and does not take into account the issue of patronage, one would never be able to understand why he translated Shakespeare's plays in the way that he did. Each translation opens with a page stating that the translation is dedicated to His Highness Maharaja Bhavsinhji Gohil. That's not all. Prabhashankar Pattani, the Chief Minister of the Princely State of Bhavnagar, would himself review the translations done by Dave and invite Dave for a discussion and provide his inputs for the improvement of these translations. In his preface to these translations, Dave mentions how these discussions with Pattani clarified various aspects of Shakespeare's dramaturgy to him. It is easy to infer from this that Dave was following the instructions from Pattani as to how these translations should be done and Pattani was also editing them wherever necessary. This also explains why Dave perhaps rendered Shakespeare's plays in prose and provided literal translations.

It is also worth remembering that one needs to access all the relevant data and information regarding the concerned translator so that one can understand and explain the difficult and complex parts of translation history. For instance, Dave had also done an adaptation of Shakespeare's All is Well that Ends Well for Arya Subodh Natak Mandali, a theatre group based in Morbi. In the preface, Dave mentions that the theatre group had asked him to provide a translation of the said play before three years. The adaptation as it is available today was published in 1906. It means that he had done it in 1903. This sharply coincides with his translation work of Shakespeare's plays undertaken between 1898 and 1917. He titled the adaptation as Chandra Raman athva Premni Aanti-ghunti. He also mentions that the theatre group did not like the adaptation but Dave still managed to get it published in 1906. Discarding the literal method of translation, he unleashes his creativity and provides a free adaptation. It is also pertinent to mention that 
the adaptation has Aurangzeb and Shivaji as characters in an adaptation based on Shakesepare's All is Well that Ends Well! On the one hand, he was working on translation of Measure for Measure as a part of the Princely State's translation project and on the other hand, he was working on the radically creative adaptation of All's Well that Ends Well. Such an adaptation clearly indicates that if provided the creative freedom, Dave would never have given literal and prose translation of Shakespeare's plays done under the instruction of the Princely State. Patronage is also a critical factor in translation history because it tends to push the translator on the margin in terms of the crucial decisions related even to the literary aspects of a translation.

A more rigorous study of patronage and censorship regarding translation of Shakespeare's plays and translations in general would serve to explain a number of things that we take for granted or consider a random act of translation history. I would probably answer a set of questions regarding the rationale, the strategies, the literary choices and overall form of translations as they exist today.

\section{When did the Translation Occur?}

Translation history is also about the exact historical moment when the translation occurs. While writers and theatre groups were happy adapting Shakespeare since 1852, the first translation proper occurs only in 1898 with Narbheshankar Pranjivan Dave's twin translations of Othello and Julius Caesar. The first translation of Shakespeare's any particular play can also be studied in the same way. Since Dave translated five plays, three other plays Measure for Measure, The Merchant of Venice and Hamlet were also translated for the first time by him in 1905, 1911 and 1917 respectively. It is interesting that As You Like It gets translated for the first time into Gujarati as late as only 1964 ! 
On the other hand, it is also interesting and fruitful to study how some later translators translated some of the same texts. More importantly, how many texts get translated again needs to be analyzed in order to understand how the translators perceived the Shakespearean plays. Gujarati translators privileged tragedies and mostly every major translator sought to translate any of the four tragedies or the tragi-comedy. There are three Gujarati translations of Hamlet attempted in 1917, 1942 and 1967 respectively. Othello gets translated twice- first in 1898 and then in 1978, after a hiatus of 80 years.

It is interesting that Macbeth gets translated for the first time as late as 1963 by Jayant Patel. However, Macbeth was translated twice too- the details regarding the year of publication are not available as yet but it is safe to infer that it was somewhere around 1964 because Jashwant Thakar, the translator mentions that he had done it for the celebration on the occasion of Shakespeare's birth anniversary in 1964. The first translation of King Lear occurs in 1983. Mansukhlal Jhaveri translated it and it was published by Gangotri Trust. King Lear did not attract Gujarati translators as much. Jhaveri was the lone translator who attempted the translation of King Lear in Gujarati.

The Merchant of Venice is arguably the most oft-translated Shakespearean play in Gujarati as it was the only play translated four times. The first translation of The Merchant of Venice occurs in 1911 which was done by Dave. It was followed by Hansa Mehta's translation in 1944. The third one was done by Krushnashankar Ambashankar Vyas in 1975. It was Jayant Patel who gave us the fourth translation but unfortunately the publication year is not yet available.

It is also interesting to study how after Narbheshakar Pranjivan Dave's last translation in 1917, there are only two translations that occur - Hansa Mehta's translation of Hamlet and The 
Merchant of Venice in 1942 and 1944 respectively. From 1917 to 1960 , there are only two plays that get translated. But from 1960 to 1990, around 10 translations of Shakespeare's different plays occur!

It gives rise to quite a few interesting questions. Was this something random that there was a period of lull in the first half of the $20^{\text {th }}$ century after Dave's translations, and suddenly there's a prolific output of translations in the second half? Was it because competent translators did not exist during the first half of the $20^{\text {th }}$ century? One cannot possibly argue such a thing. Was it a single factor that gave rise to more than 10 translations in the second half or was it a combination of factors? Was it purely coincidental or was it carefully sought by writers, scholars and translators working in tandem? These questions form in themselves an area of research to be explored. However, the important point here is that when one asks the question as to when the translations occurred, it can lead one to discover some crucial interpretations which will otherwise escape the traditional model of translation history wherein one is busy documenting "who translated what".

\section{Where did the Translation Occur?}

Where translators work, live and get the translations published can also offer an insight into the history of how each part of the region in question produced more or less translation in comparison to their counterparts. Whether a particular region produced many translations or did not produce any translation is also interesting because it points us the direction of the literary pursuits taking place or not taking place in the given region. On the other hand, one might discover that a part of the region was quite active in literary activities but did not produce translations. A part of the region which was not prominent in any other way but produced important translations deserves a deeper exploration. 
In the case of the translation of Shakespeare's plays and sonnets into Gujarati, the study of location offers interesting insights. Broadly speaking, Bhavnagar, Ahmedabad and Surat and Mumbai produced most of the translations. The first translations occurred in a place no one expected - Bhavnagar. It was a first-class Princely State and attracted artists and scholars not just from Gujarat but across India. It provided patronage to artists and scholars from time immemorial. Hence, it is plausible to those who know its rich cultural history that Shakespeare's translations could occur there. However, it is also interesting that the Princely State informally encouraged several translations and later set up a fund for systematic promotion of translation but the translation of Shakespeare's plays was one and the only time that Shakespeare's plays or any other canonical texts get translated in Bhavnagar. There were one or two translations from English into Gujarati as far as English literature is concerned but no sustained effort or engagement with either Shakespeare or English literature. So, Bhavnagar earns its glory based solely on this lone endeavour of translation of Shakespeare's five plays.

Surat is interesting for its historic relationship with Shakespeare. In 1852, a Parasi theatre group had performed an adaptation of Shakespeare's The Taming of the Shrew at Andrews Library in Surat. Apart from this, Surat witnessed a flurry of translations mostly by one translator namely Jayant Patel. Patel was a lecturer in Department of Gujarati at MTB Arts College, Surat. Is it a sheer coincidence that a great Shakespeare scholar namely Vishuprasad Trivedi also worked in the same college as a lecturer of English? In fact, it was Trivedi who was about to retire and asked Patel to fill his position. Since Patel was driven by a desire to help his students understand Shakespeare's plays, he went on to translate four plays into Gujarati. This was a unique instance because these 
translations occurred purely for a limited readership of students.

Ahmedabad wouldn't surprise us as far as translation is concerned as it was the hub of literary discourses, literary organizations leading to a number of literary activities. Many scholars and writers had made it their home. Hence, it would be apt to assume that Ahmedabad had the right cultural conditions for translation. As an exception, Hansa Mehta's translations were published from Mumbai.

Baroda is a unique place in this context. It was perhaps the better-known cultural centre for literature and translation than any other city in Gujarat. It did have a translation department that Sayajirao had put in place and translation flourished there more than most of the places in Gujarat. However, it is baffling that Baroda does not produce any translation of Shakespeare's plays into Gujarati.

Baroda had one or two strands that connected it to a translation of Shakespeare's plays. Firstly, Mohamed Rupani stayed in Baroda when he studied at Baroda High School during 192834 and Baroda College during 1934-38. Rupani mentions in his preface that the teachers at Baroda College introduced him to the best of English poetry which laid the foundation for his original work in terms of collection of poetry as well as his translation of Shakespeare's sonnets and plays. The only other thread that connects Baroda to translation of Shakespeare's plays is that Hansa Mehta who translated Shakespeare's Hamlet and The Merchant of Venice into Gujarati was the first Vice Chancellor of the MS University which was earlier known as Baroda College. Apparently, it appears to be related. But Mehta became the Vice Chancellor only later in 1949 well after translating Shakespeare's plays! Barring the chance elements that connect Baroda to Shakespeare's Gujarati translation, there is no evidence that Baroda engaged with 
Shakespeare. Interestingly enough, Baroda offers translations of all kinds except Shakespeare's works!

A study of translations as they occurred at different locations of a geographic region can provide the trajectory of translation and offer some new insights regarding translation history.

\section{Blanks, Mistakes and Forgotten Translations}

Translation Studies is a relatively new discipline and translation history is just an emerging area. Therefore, it is understandable that we don't have accurate and adequate translation history at the moment. However, there's a growing discussion and discourse on the significance and need for rigorous research in the area of translation history. Therefore, it will be necessary to address the basic issues in translation history so that the future researchers don't have to worry about whether the chronology that they have is correct or not. They should not be in a position to doubt their own hypothesis because of lack of data. In future, a more detailed and sustained effort at translation history would be possible only if we put in place the foundation of such research at present. The present-day scholars and experts will need to undertake systematic work in the direction of translation history in order to ensure that we have at least removed the obscurity surrounding parts of translation history and rendered the chronology accurate.

To start with, serious effort should be put into ascertaining the firsts- the first Shakespearean adaptation and translation with full details, the first translation of English canonical texts, the first translation of knowledge texts such as Bhartrahari's Vakyapadiya, the first translation of culturally central texts such as the Ramayana, the Gita, and the Bible etc. It is not merely about establishing who translated them or when but also placing these translations and translators in the historical context and acquire as much information about its historical 
context as we can. It may be worth noting that the terminology of "Blank Spaces", "Mistakes" and "Forgotten Texts" has been borrowed from a book titled Charting the Future of Translation History, edited by Georges L. Bastin and Paul F. Bandia and published by University of Ottawa Press, Canada in 2006.

In the case of Shakespeare's plays translated into Gujarati, translation must address the issues related to Blank Spaces, Mistakes and Forgotten Texts.

\section{Blank Spaces}

Since translation history is in its "infancy" or "adolescence", the narratives of translation history that we have may be far from being accurate. There are some obvious blank spaces that we need to take into consideration. The blank spaces in this context indicate lack of information or data regarding a translation, translator or any other relevant information. Due to such blank spaces, translation history suffers from omissions that make the translation history flawed and misleading. The interesting thing about the blank spaces is that we come to know about the blank spaces only when we discover new information that leads to these blank spaces and there's the Eureka moment when we realize that this was a blank space.

In the case of Shakespeare's translators and translations, there are a number of blank spaces because details are missing in the case of almost each translator and translation.

However, here's a case of blank space: Krushnashankar Ambashankar Vyas translated Shakespeare's The Merchant of Venice into Gujarati in 1975. It is not an old translation but it hardly finds a place in the documentation of translations in 6 volumes of Gujarati literary history published by Gujarati Sahitya Parishad. There is no mention of the translator or the translation in Gujarati Sahitya Kosh either. Granth ane 
Granthkar also fails to document this particular translator and translation.

It is largely an undocumented translation. There is little information that one can find about the translator. The only source of any information is the translation itself. Fortunately, the translation is available and mentions a few details about the translation and the translator. Krushnashankar Ambashankar Vyas retired as Deputy Collector and he was a Dakshina Fellow at Gujarat College, Ahmedabad. After retirement, he undertook these translations. It is possible to assume that he worked on his translations in complete anonymity and hence, no one knew about these translations. But that was not the case. In fact, the translation carries two "evaluations" as Vyas puts it. The two evaluations are reviews of the translation by Anantrai Rawal and Jaydev Shukla. Ananatrai Rawal mentions in his review that Vyas attempted the translation at the age of 65. It may be borne in mind that Vyas was born in 1899. It means that he translated it in the year 1964 and it got published in 1975. Was it a coincidence that Vyas translated it in 1964, the year that Gujarati litterateurs and translators celebrated as $400^{\text {th }}$ birth anniversary of Shakespeare? What happened between 1964 and 1975 is also a mystery- a blank space during which the translation awaited its publication.

The life and work of Krushnashankar Ambashankar Vyas is a blank space. His translation as it exists is the piece of puzzle that we have. Translation history is all about undertaking the challenge to put together the rest of the pieces and reconstruct the full narrative of the life and work of Vyas.

\section{Mistakes}

Translation is not only about putting together the accurate information but it is also about identifying and correcting the "mistakes". Unless we eradicate mistakes and make the account of history error-free, it would not be possible to put 
together translation history that is a reliable and authentic account of how translations occurred in a given time period.

When there is inaccurate or insufficient information, it adversely affects translation history in a number of ways. Firstly, it leads to inaccurate chronology. Here's an illustration:

Deepak Mehta, the renowned scholar and critic, penned a book called Ognismi Sadini Gujarati Granth Samruddhi, which he describes it as "Articles on $19^{\text {th }}$ century Gujarati books and writers" published in 2010. It was published by Darshak Foundation. It was evidently a collection of his articles on the salient aspects pertaining to the $19^{\text {th }}$ century Gujarati literature. As an eminent scholar, he provides rare and valuable information on several aspects of Gujarati literature as it developed in the $19^{\text {th }}$ century. However, a mistake or two pertaining to translation history might have crept into his work.

The book contains an article titled "Shakespeare na Natak no Pehlo Anuvad" which can be roughly translated as "The First Translation of Shakespeare's Play". The article deals with Nhanabhai Rustamji Ranina's book titled Shakespeare Natak published in 1865. Mehta argues that this book which contains the first ever translation of Shakespeare's plays. However, the fact is that it contains the adaptations of Shakespeare's Comedy of Errors and Othello. Therefore, the title of his article about the first translation of Shakespeare's play falls under the category of "Mistakes" in terms of translation history. Somewhere in the article, he does clarify that the adaptations contained in the book are not translations proper but the title of the article seems to indicate that Mehta is introducing readers to the first ever translation of Shakespeare's play. It should also be borne in mind that Mehta 
points out at the outset that even the most authentic history books such as Hasmukh Baradi's Gujarati Theatre no Itihas (History of Gujarati Theatre) and Mahesh Chowksi's doctoral work titled Gujarati Natyasahityano Udbhav ane Vikas (Origin and Development of Gujarati Dramatic Literature) also don't provide accurate information regarding the first translation/adaptation of Shakespeare's plays. He goes on to say that the earliest translation/adaptation documented was titled Golabsinh, an adaptation of Shakespeare's Cymbeline published in 1881. However, it is Mehta who has unearthed the translation/adaptation - Ranina's Shakspeare Natak which was published earlier than the one published in 1881. Therefore, he claims to have corrected the history in this way.

However, the fact of the matter is that first of all, the title "the first Translation of Shakespeare's Play" was not quite accurate as Ranina's book contained adaptations and not the translation as Mehta claims. To his credit, Mehta does rectify this mistake that occurs in 2010 in another article on the same topic titled "Shakespeare na Pratham Rupantarkar" ("First Writer who Adapted Shakespeare's Play") in the next book Ognismi Sadina Gujarati Granth ane Granthkar (Articles on $19^{\text {th }}$ Century Books and Writers) published in 2015. Now he considers Ranina as the writer who adapted Shakespeare's plays. It is possible that the articles might have been published earlier but compiled later in 2015. This does rectify one minor mistake, although such mistakes should be avoided in scholarly writings of his kind which can influence readership and next generation of scholars and researchers. Anyway, the minor mistake is tolerable but the major mistake is the issue of chronology. Unfortunately, Ranina's Shakespeare Natak (1865), the book containing the adaptation of Shakespeare's two plays, was not the "first" translation or adaptation. There were adaptations which were done prior to 1865 . Taliyarkhan's Nathari Firangiz Thekane Aavi, an adaptation of 
Shakespeare's Taming of the Shrew was the first adaptation not just in Gujarati but the first ever adaptation in any modern Indian language. It is also worth mentioning that most of the translation/literary historians don't mention that such an adaptation existed. Even if a literary historian such as Madhusudan Parekh mentions this adaptation, only as a passing reference that such an adaptation was performed. With expertise on the contribution of Parsis to Gujarati literature, Parekh fails to provide any further details regarding the translator, the year of performance and publication etc. Such is the dire state of literary and translation history!

To set things right once and for all, it is necessary to place this adaptation in history with all the requisite details. To start with, Nathari Firangiz Thekane Aavi was performed at Andrews Library, Surat in 1852. Some might argue that Mehta is referring to a "published adaptation". However, his article title only mentions "The First Writer Who Adapted Shakespeare's Play". It does not specify whether he is referring to the first ever adaptation, whether on stage or published one. In the case of the first adaptation, Nathari Firagniz Thekane Aavi qualifies to be the first one in both the respects- stage performance and publication. It was performed in 1852 and published in Stribodh, a magazine for women, in May 1861, earlier than Ranina's Shakespeare Natak published in 1865. It is interesting to note that Mehta is based in Mumbai and Stribodh was also published from Mumbai. With a little more rigour, Mehta could have averted an error of projecting Ranina's Shakespeare Natak as the first ever translation/adaptation in history. This is not about finding faults with an individual because Mehta has published extremely relevant and insightful works on the $19^{\text {th }}$ century Gujarati literature and its history. It is merely an illustration of how one may inadvertently subvert the history by privileging a translation or adaptation whatever the case may be. If esteemed 
scholars and researchers such as Deepak Mehta can falter, it is obvious that most of us are prone to inaccurate documentation leading to skewed translation history. Therefore, it is necessary to add a little more rigour to the way we do translation history. The conventional approach to translation history involves the researcher or translation historian sticking to conventional ways of accessing information such as volumes of history of Gujarati literature, Sahitya Kosh etc.

Generally speaking, translation historian, if he/she wants to avoid any errors, should stop being an armchair translation historian first and step out and explore the universe of data that exists- the Gazettes, Administration Reports prepared by the British, catalogues, previous research undertaken, the history of the region that the concerned translation belongs to, history of reform, education, theatre activities etc., letters and memoirs, biographies and auto-biographies of not just the translator but of all those writers and other important individuals around him and any other documents that may throw some light on the translation history at hand. The reason why it is necessary to be thorough in accessing all available information is that once we access all the data that we can, we will have fuller and deeper understanding of history and there would be no blank spaces or mistakes.

\section{Forgotten Translations}

This is interesting because it is similar to "blank spaces" in the sense that it is also missing from the history but it is different because it is familiar but forgotten. Forgotten translations are those that are documented in some way somewhere but forgotten over a period of time. Here're a couple of cases:

Narbheshankar Pranjivan Dave translated 5 of Shakespeare's plays - Othello, King Lear, Measure for Measure, The 
Merchant of Venice and Hamlet into Gujarati during 1898 to 1917. It is documented somewhere or the other in a sketchy manner but these translations are forgotten. They are forgotten in the sense that they don't form a part of translation discourse or translation history. No translation expert or historian engages with these translations. Almost every translation scholar in Gujarat knows that Dave translated these plays into Gujarati but a scholarly study and analysis of these translations or the translation history related to these translations has not yet been attempted. It is not just that these translations are forgotten as translations; they are forgotten as the some of the earliest Gujarati translations ever of Shakespeare's plays. How can translation history disregard the earliest translations of any text, leave alone Shakespeare? Wouldn't it be a great gesture of humility to start the work on translation history of Shakespeare's plays with the study and discourse of the earliest translations? Wouldn't it prove beyond a point that we are committed to translation history and its development as a significant area under translation studies? These are disconcerting questions but translation history cannot be pursued without addressing these questions about the first but forgotten translations. First and foremost, the earliest translations will help us set the chronology right. It will also help us place the translators and translations in history. Dave will surely get his rightful place as the first few translators who rendered Shakespeare's plays into Gujarati. It will also be possible to place his translations in the context of subsequent translations.

\section{2}

Jayant Patel translated 4 of Shakespeare's plays namely Othello, Macbeth, The Merchant of Venice, As You Like It into Gujarati around 1964. Patel's name and work does not figure in the usual sources of information in terms of literary history 
such as volumes of History of Gujarati Literature etc. Even if there is some information available, it is generally incomplete and does not shed light on the work attempted under the given circumstances. The fact that he was a lecturer in Gujarati and he attempted the translations should be sufficient for a translation historian to take note and explore further. Moreover, he revealed in a telephonic conversation with the researcher that he had done the translations for his students of BA and MA who had Gujarati as the major. Such an endeavour for students sets it apart from the rest of the translations because other translations were all aimed at disseminating Shakespeare's works for the masses. In this way, Patel's translations make it a singular case in the translation history of Shakespeare's works in Gujarati.

Jayant Patel was not a literary figure and was not in the inner circle of the scholars at the time of his translations. He was a teacher who humbly translated these texts for the purpose of helping his students. This is precisely why his translations and his contribution seem to have been forgotten.

In spite of being published in 1964, Patel's translations don't form a part of translation discourse in Gujarat. Jayant Patel's life and work form a classic example of forgotten translations and translators. We have yet to wake up to his contribution and study the way he translated Shakespeare's plays.

\section{Conclusion}

Translation history is a complex exercise. It represents a composite enterprise in which several aspects affect the translation. Without taking these aspects into consideration, it would not be possible to comment on any given translation with some authority. Clearly, the onus is on the translation researchers and scholars. If we want to do responsible and serious translation history, we will need to maintain the discipline that pursuit of history always calls for. Else, we will 
end up doing shabby and irresponsible translation history which would eventually be not only inaccurate but it will also be a disservice to the study of translation.

Therefore, we must commit ourselves to translation history and continue to study and revisit the versions of translation history that exists. This paper is merely a version of translation history related to Shakespeare's works, there's no finality to any of the arguments or interpretations contained in this endeavour. As true and committed translation historians, we must continue to explore the history that surrounds the translation of Shakespeare's works and consider it as a never-ending narrative. If we keep exploring, new facts and information will keep emerging leading us newer interpretations.

It is important to emphasize upon the need to continue to explore translation history in a rigorous and consistent manner. What is meant by 'rigorous' here is that it is not enough to consult the conventional sources and resources to write a paper or book on translation history. In fact, we should widen the scope of exploration by resorting to diverse sources. Unless we have at our disposal all possible information and facts, it would not be possible to arrive at a plausible interpretation or argument that explains the flow of events with respect to translation history. Being a translation historian is a full-time occupation; there's no room for casual attempts and pursuits for garnering attention.

Shakespeare in Gujarati is a timeless and endless saga and we must devote ourselves to its study so that we can recreate the historical context in which the engagement with Shakespeare through translation occurred over a period of more than 150 years. It would be simplistic to assume that one such effort of translation history pertaining to Shakespeare's plays would be sufficient. There are many more interesting discoveries that await us in terms of translation history of Shakespeare's works 
in Gujarati in future. To adequately articulate this, it would be apt to resort to Shakespeare and cite Hamlet's lines:

"There are more things in heaven and earth, Horatio, than are dreamt of in your philosophy" (Hamlet Act 1, Scene 5).

\section{References}

BASSNETt, SusAN AND ANDRÉ LEFEVERE. (ed.). 1999. Translation, History and Culture. London: Routledge.

Bassnett, Susan And Harish Trivedi. (ed.). 1999. Post Colonial Translation. London: Routledge.

Bastin, George L. AND PAul F. BAndiA. (ed.). 2006. Charting the Future of Translation History. Ottawa: The University of Ottawa Press.

BHATT, S. R. 1970. Shakespeare. Gujarat University.

D’hulst, LIEVEN. 2010. Translation History. In Yves Gambier and Luc Van Doorslaer (eds.), Handbook of Translation Studies II. 397-405. Amsterdam: John Benjamins Publishing Company.

DAHYARAM, KAVISHVAR DALPATRAM. 1933. Gujaratna Ketlak Aitihasik Prasango and Vartao. Shri Forbes Gujarati Sabha.

DAVE, HARINDRA. 2014. Umashankar Joshi. Gurjar Granth Ratna Karyalaya.

Dave, Narbheshankar Pranjivan. (trans.). 1898. Julius Caesar. Bhavnagar State.

DAVE, NARBHESHANKAR PRANJIVAN. 1898. Othello. Bhavnagar State.

DAVE, NARBhEShankAR PRANJIVAN. 1906. Measure for Measure. Bhavnagar State.

Dave, NARBhEShankar PRAnJIVAn. 1911. The Merchant of Venice. Bhavnagar State.

Dave, NARbHeshankAR PranjIVAN. 1917. Hamlet. Bhavnagar State.

De LotbiniÈre-Harwood, SusAnNe. 1990. Preface to Lise Gauvin's Letters from Another. Toronto: Women's Press. 
DHARAIYA, R. K. 1980 Contribution of Gaurishankar Udayashankar Oza: Gaga Oza in the Development of Bhavnagar. Diss. Gujarat University.

Dhruv, KeShav HARSHAD. 1939. Sahityaane Vivechana. Gujarat Vernacular Society.

Fisher, Beatrice And Nisbeth, Matilde Jensen. 2002. Translation and the Reconfiguration of Power Relations. Berlin: Deutsche Nationalbibliothek.

GAZDAR, FARAMJI MANCHERJI. 1942. Bhavnagar na Jarthostio no Sankshipt Itihas. Bhavnagar Parsi Jarthosti Anjuman.

GoHIL, GAMBHIRSINHJI. 2012. Prajavatsal Rajvi. Rajvi Prakashan.

JhaVeri, Mansukhlal. (trans.). 1967. Hamlet. Sahitya Akademi.

JHAVERI, MANSUKHLAL. (trans.). 1978. Othello. Gangotri Trust.

JHAVERI, MANSUKHLAL. (trans.). 1983. King Lear. Gangotri Trust.

JHAVERI, MANSUKHLAL. 1935. Bhashantarni Kala. 2012 Agiyarma Gujarati Sahitya Parishad Sammelanno Aheval. 469-472.

Joshi, UMASHANKAR, ET AL. (ed.). 1960. Niriksha. Gurjar Granth Ratna Karyalaya.

JoSHI, UMASHANKAR, ET AL. (ed.). 1978. Shiv Sankalp. Gurjar Granth Ratna Karyalaya.

JOSHI, UMASHANKAR, ET AL. (ed.).1986. Isamu Shidaane Anya. Gurjar Granth Ratna Karyalaya.

JOSHI, UMASHANKAR, ET AL. (eds.). 1973-2017. Gujarati Sahitya no Itihas. Vol 1-7, Gujarati Sahitya Parishad.

MentA, C. C. (ed.). 1964. Shakespeare Drshyavali. Gujarat Sangeet Nrutya Natya Akademi.

Menta, C. C. 1964. Shakespeare and the Gujarati Stage. Indian Literature 7(1). 41-50. 
Sunil Sagar

MeHtA, DeEPAK. 2010. Ognismi Sadini Gujarati Granthsamruddhi (Articles on $19^{\text {th }}$ Century Gujarati Books and Writers). Darshak Foundation.

MEHTA, DEEPAK. 2015. Ognismi Sadina Granth-Granthkar. Rangdwar Prakashan.

Mehta, HansA. (trans.). 1942. Hamlet. N. M. Tripathi \& Co.

MEHTA, HANSA. (trans.). 1944. The Merchant of Venice. N. M. Tripathi \& Co.

O'Sullivan, CAROL. 2012. Rethinking Methods in Translation History. Translation Studies 5 (2). 131-138.

PARASHARYA, MuKUndARAY. 1984. Satyakatha 2. Pravin Prakashan.

PAREKH, BHANJI GOKUL. (trans.). 1874. Karunaras Julius Caesar Natak. Kathiawad Printing Press.

Patel, DhanjiBHai. 1931. Parsi Natak Takhtani Tavarikh (A History of Parsi Theatre). Kaysar-e- Hind Press.

PATEL, JAYANT. (trans.) 1963. Macbeth. The Popular Book Store.

PATEl, JAYANT. (trans.). 1963. Othello. The Popular Book Store.

PATEL, JAYANT. (trans.). 1963. The Merchant of Venice.The Popular Book Store.

Patel, JayAnt. (trans.). 1964. As You Like It. The Popular Book Store.

PYM, A. 1998. Method in Translation History. Manchester: St. Jerome.

PyM, ANTHONY. 2017. Humanizing Translation History. HERMES - Journal of Language and Communication in Business 22.42: 23.

RAWAL, NALIN. (trans.). 1992. The Tempest. SNDT Women's University.

Rupani, MoHAmed, (trans) 1979. As You Like It-Aapni Pasandagi. M. J. Rupani. 
Shakespeare in Gujarati:...

RuPANI, MOHAMED. (trans.). 1977. Shakespeare na 159 Sonnet. Gyanjyoti Prakashan Mandir.

RuPANI, Mohamed. (trans.). 1979. As You Like It-Aapni Pasandagi. M. J. Rupani.

THAKAR, JASHWANT. (trans) 1969. Richard III. Jashwant Thakar.

THAKAR, JASHWANT. (trans.). 1964. Macbeth.

VyAS, KRUSHNASHANKAR AMBASHANKAR. (trans.). 1975.

Venice no Vepari. Gurjar Granth Ratna Karyalaya. 